\title{
ARTITIE

\section{THE EFFECT OF ENZYME PREPARATIONS WITH DIFFERENT DIRECTION ACTION ON RHEOLOGICAL PROPERTIES OF WHEAT DOUGH}

\author{
Tatyana Lebedenko, Natalia Sokolova, Andriy Onischuk \\ Department of Bakery, Confectionary, Pasta and Food Concentrates Technologies, \\ Odessa National Academy of Food Technology, Ukraine \\ Kanatnaya Str. 112, Odessa 65039, Ukraine \\ phone: +380487124144 mobile: +380983020887 \\ e-mail: techinstoffood@gmail.com
}

\begin{abstract}
The physical properties of the dough have a great importance on bread making technology, since it influence on operate of dough equipment, on ability of the dough pieces to retain carbon dioxide and keeping their shape during the proofing and baking processes. They directly depend on the unstable, in the last decade, baking properties of flour. All this factors complicate the work of bakeries. One of the ways to solve this problem and to regulate the baking properties of flour for the purpose of producing products with the required quality is to use of bakery improvers.

The results of the study are presented there, the effect of enzyme preparations, which were added to the wheat flour, on the structural and mechanical properties of the dough from this flour are reported.

The results of these enzyme preparations effect on the process of dough formation, its rheological properties during time of development and during fermentation time (135 minutes) are presented. The regularities of the action on the water absorption of dough, its physical, chemical and rheological properties with enzyme preparations during the technological process are analyzed.

The recommendations about using enzyme preparations of a multidirectional action are given. Keywords: enzymes, bakery properties of wheat flour, rheological properties of wheat dough.
\end{abstract}

\section{NTRODUCTION}

The technological process of dough preparation is a transformation of flour biopolymers into an elastic-plastic spongy structure by the variety microbiological, biochemical, and colloidal processes. Its intensity and direction depend on the quality of the raw materials and first of all - the flour.

At the same time, the quality of the raw materials is constantly changing for different reasons. There are the change in climatic conditions and innovative approaches in the selection, cultivation and processing of wheat. To eliminate problems with the quality of flour in flour mills try to blend several batches, but this approach is almost difficult to implement and does not always give the essential result. Technologists at bakeries are looking for the way to correct the baking properties of flour by introducing certain technological methods but due to the widespread use of accelerated methods of dough preparation, the possibilities become less.

One of the natural ways to improve the properties of flour is the addition of dry wheat gluten, but it is solved only one of the problems that are associated with the quantity and quality of the protein complex of flour. It is completely useless if the flour have problems with the enzyme system.

The developments of biotechnology and scientific discoveries in the field of enzymology have made using enzyme preparations an indispensable participant in many food technologies [1]. Enzymes can modify and improve the functional, nutritional and sensoric properties of 


\section{ARTTIE $Y$}

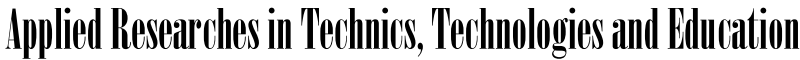

Journal of the Faculty of Technics and Technologies, Trakia University https://sites.google.com/a/trakia-uni.bg/artte/

ingredients and products, and therefore enzymes have found widespread applications in processing and production of all kinds of food products.

In food production, enzymes have a number of advantages. First, enzymes are used as alternatives to traditional chemical-based technology. Enzymes can thus replace synthetic chemicals in a wide range of processes. This allows advantages in environmental performance of processes by lowering energy consumption levels and biodegradability of products. Furthermore, since enzymes are more specific in their action than chemical reactants, enzyme-catalyzed processes have fewer side reactions and byproducts. The result is higher quality products and less pollution. Enzymes can catalyze reactions under very mild conditions, allowing mild processing conditions which do not destroy valuable attributes of foods and food components [1].

Enzyme preparations for the bakery industry are produced under various trade names, for example, Novozym 677 (enzyme preparation of lipase), Fungamil 2500 BG (enzyme preparation of amylase), Pentopan 500 BG (enzyme preparation of pentosanase), etc. There are enzymatic preparations of oxidative, reducing action and complex enzyme preparations, which in their composition have a number of enzymes. The effect of enzymes on flour and dough is very diverse. If enzyme preparations are selected correctly, the positive effect of their use is almost guaranteed. Thanks to the active use of enzyme preparations, it is possible to correct the baking properties of flour in a quite wide range.

The purpose of this study was to determine the effect of two enzymes, which have a multidirectional effect on the rheological properties of the dough during the batching and its fermentation. Since only the final result of the action of these enzymes is known, there are no recommendations on the methods of dough preparation, nor is the influence of such enzymes directly on the kneading and fermentation process of the dough.

As a source of protease, the "Neutraz" was used, which is a microgranulate of brown color. The average particle size was 300 microns. "Neutraz» is a neutral protease obtained by the production of a purified, genetically unmodified strain of Bacillus amyloliquefaciens. Its activity is $1.5 \mathrm{AU} / \mathrm{g}$ ( $\mathrm{AU}=$ units of Anson's activity). The optimum operating conditions are temperatures up to $70^{\circ} \mathrm{C}, \mathrm{pH}$ 5.5-7.5 [2].

"Glyuzim Mono 1000» was used as a source of glucose oxidase. The glucose oxidase, which produced by Aspergillus oryzae, was used as an oxidizing enzyme. Glucose oxidase is an enzyme that catalyses the oxidation of glucose into hydrogen peroxide and gluconic acid. As a reductive enzyme was used bacterial protease, which involved in digesting long protein chains into shorter fragments by splitting the peptide bonds that link amino acid residues. The preparation itself is a yellowish-grayish, loose, non-dusting agglomerated granulate and flour. The average particle size is 150 microns in the range of 50-212 microns. "Glyuzim Mono 10000 » is stable at a pH of 3.5 to 7.0 and at temperatures up to $50{ }^{\circ} \mathrm{C}$

The preparations were used in a dosage recommended by the manufacturer for gluco oxidase of $1 \mathrm{~g}$ of preparation per $100 \mathrm{~kg}$ of flour, for protease $-2 \mathrm{~g}$ of preparation per $100 \mathrm{~kg}$ of flour [2]. Wheat flour was used in the research.

\section{METHODS}

\subsection{Determinate rheological properties during mixing by Brabender Farinograph}

The Farinograph measures and records the mechanical resistance of the dough during mixing and kneading. The rheological characteristics of dough prepared from control wheat flour and wheat flour with enzymes were determined by Brabender Farinograph (Brabender OHG, Duisberg, Germany) according to AACC method Nos. 54-21 (2000) [3] .

Sample weight on $14 \%$ moisture basis $(\mathrm{mb})$ was calculated using the eq. (1) 


\section{ARTITE} Ipplied Researl rhes in Technics, Technologies and Bduration Journal of the Faculty of Technics and Technologies, Trakia University https://sites.google.com/a/trakia-uni.bg/artte/

$$
\text { Flour weight on } m b=\frac{100-14}{100-M} \times \text { flour weight }
$$

where $\mathrm{M}$ = flour moisture content in \%.

Appropriate weight of flour sample $(10 \mathrm{~g}$ on $14 \% \mathrm{mb})$ was placed in the mixer of the farinogramma, which was thermostatically controlled by means of water jacket at a temperature of $30^{\circ} \mathrm{C}$. Cold distillate water at $30^{\circ} \mathrm{C}$ was added to the sample through the attached burette until optimum water absorption content was absorbed by the dough when the farinogram curve was on the 500 line. A fresh sample was taken and the process was repeated using the appropriate water absorption for the mixing and development process. The development of the dough and the resistance offered to mixing were recorded on the farinogram. Parameters for each farinogram were determined according to Locken [4].

The farinograph water absorption is the volume of water, expressed in $\mathrm{ml}$ per $100 \mathrm{~g}$ of flour at $14.0 \%$ moisture content, required to produce a dough with a maximum consistency of 500 FU.

\subsection{Determinate rheological properties during fermentation by Extensograph Brabender}

The rheological characteristics of dough during fermentation were determined by Extensograph Brabender (Brabender OHG, Duisberg, Germany). The standard extensigraph method (AACC Method 54-10.01) [5] uses the Farinograph for the preparation of dough in the presence of $2 \%$ salt at reduced water absorption (Farinograph absorption minus 2-3\%). After mixing in the Farinograph, each dough was divided into three pieces (150 g/piece) and proofed in a humidity chamber at $30^{\circ} \mathrm{C}$. After 45,90 and $135 \mathrm{~min}$ of proofing, one piece was stretched until it breaks and re-formed (rounded and rolled). The results were recorded on extensograms. Brabender extensograph gave the resistance to constant deformation after $50 \mathrm{~mm}$ stretching (R50), the extensibility (E), the ratio R50/E, energy. From these curves, the rheological properties of the control sample flour and the influence of flour additives (enzymes) on the flour quality were clearly recognized [5].

\section{EXPERIMENTAL}

The rheological parameters of wheat flour samples are shown in Table 1 and Table 2.

Table 1. Rheological properties of flour during mixing and kneading (Farinograph Brabender characteristics)

\begin{tabular}{|l|c|c|c|}
\hline \multirow{2}{*}{\multicolumn{1}{|c|}{ Index }} & \multicolumn{3}{c|}{ Flour samples } \\
\cline { 2 - 4 } & Control & With glucose oxidase & With protease \\
\hline Water absorption, \% & 60 & 63 & 63 \\
\hline Consistence, Brabender units & 500 & 500 & 500 \\
\hline Arrival time, min & 2,5 & 2,5 & 4,5 \\
\hline Dough stability, min & 7 & 10 & 3,5 \\
\hline Elasticity, Brabender units & 60 & 70 & 50 \\
\hline $\begin{array}{l}\text { Degree of softening, Brabender } \\
\text { units }\end{array}$ & 140 & 110 & 180 \\
\hline
\end{tabular}

IRITIE Vol. 5, No. 4, 2017 ISSN 1314-8788 (print), ISSN 1314-8796 (online), doi: 10.15547/artte.2017.04.009 


\section{ARTITIE}

Ipplied Researleches in Technics, Technologies and Eductation Journal of the Faculty of Technics and Technologies, Trakia University https://sites.google.com/a/trakia-uni.bg/artte/

Table 2. Rheological properties of flour during dough proofing (Extensograph Brabender characteristics)

\begin{tabular}{|c|c|c|c|}
\hline \multirow[b]{2}{*}{ Index } & \multicolumn{3}{|c|}{ Flour samples } \\
\hline & Control & $\begin{array}{c}\text { With glucose } \\
\text { oxidase }\end{array}$ & With protease \\
\hline \multicolumn{4}{|l|}{ After 45 min of test } \\
\hline Area below the curve (energy), $\mathrm{cm}^{2}$ & 132 & 170 & 105 \\
\hline Resistance to extension $(5 \mathrm{~cm})$, Brabender units & 620 & 780 & 380 \\
\hline Extensibility, MM & 130 & 115 & 115 \\
\hline Ratio number (Resistance $5 \mathrm{~cm} /$ extensibility) & 5,2 & 6,7 & 2,6 \\
\hline \multicolumn{4}{|c|}{ After 90 min of test } \\
\hline Area below the curve (energy), $\mathrm{cm}^{2}$ & 105 & 152 & 74 \\
\hline Resistance to extension $(5 \mathrm{~cm})$, Brabender units & 820 & 720 & 300 \\
\hline Extensibility, MM & 110 & 90 & 138 \\
\hline Ratio number (Resistance $5 \mathrm{~cm} /$ extensibility) & 8,2 & 8,0 & 2,7 \\
\hline \multicolumn{4}{|c|}{ After 135 min of test } \\
\hline Area below the curve (energy), $\mathrm{cm}^{2}$ & 110 & 132 & 53 \\
\hline Resistance to extension $(5 \mathrm{~cm})$, Brabender units & 820 & 730 & 120 \\
\hline Extensibility, MM & 117 & 140 & 183 \\
\hline Ratio number (Resistance $5 \mathrm{~cm} /$ extensibility) & 9,5 & 5,2 & 0,65 \\
\hline
\end{tabular}

\section{RESULTS}

It has been established that the addition of enzymes, both oxidative and reducing action, leads to an increase in the water-absorbing capacity of flour by $5 \%$, which in the future will positively affect the yield of bread.

The water absorption index mainly depends on the properties of the main components of the flour: gluten and starch. For correct interpretation, it must be compared with other parameters obtained on the Farinograph. Because high water absorption combined with a low dilution rate (less than 80 units) can indicate good baking properties of flour, while high water absorption combined with a high degree of dilution is vice versa.

After a rapid increase in the optimum physical properties of the dough, no less rapid deterioration of the dough follows, explained mainly by the ongoing proteolysis processes, this process can be characterized by an indicator of the degree of dilution. Stability and degree of dilution are parameters of gluten quality that describe the viscoelastic properties of the formed gluten complex. In practice, higher stability and a lower degree of softening indicate that the dough will be able to withstand prolonged mechanical treatments. An increased degree of dilution is a particularly important indicator of proteolytic degradation of gluten.

As a result of the addition of the glucose oxidase enzyme, this indicator decreases by $27 \%$ compared to the control sample. This fact may indicate an intensive course of oxidative processes, which leads to a strengthening of gluten and an increase in the stability of the dough by $30 \%$. In contrast, protease doubles the stability of the dough from 7 to 3.5 minutes and increases the dilution rate by $28 \%$.

During the fermentation, the regularities were preserved, so when using the oxidizing enzyme after 45 minutes the energy of the dough, which characterizes the strength of the flour, increased by $28 \%$ compared to the control, after 90 minutes the opposite effect was observed and at 135 minutes the energy increase by $29 \%$ while the index of extensibility of the dough for 45 and 90 minutes of fermentation was less, for an average control of $17 \%$, after 135 minutes of fermentation, the extensibility increased by $19 \%$.

IRITIE Vol. 5, No. 4, 2017 ISSN 1314-8788 (print), ISSN 1314-8796 (online), doi: 10.15547/artte.2017.04.009 


\section{ARTTIE $Y$}

Ipplied Resseirlores in Technics, Technologies and Educration

Journal of the Faculty of Technics and Technologies, Trakia University https://sites.google.com/a/trakia-uni.bg/artte/

The sample with protease during the fermentation time had the same trend, so the energy of dough decrease the entire test period by $25 \%, 41 \%$, and $107 \%$. It was noted that the longer the action time of the enzyme, the more effective its effect becomes. At the same time, the elongation in the first 45 minutes was different from the control, not significantly after 90 and 135 minutes, this figure increased by $20 \%$ and $36 \%$, but the resistance to stretching throughout the period changed more significantly by $63 \%, 173 \%$, and $563 \%$.

\section{CONCLUSIONS}

Although the mechanism of action of glucose oxidase is still not completely understood, a possible explanation is that the hydrogen peroxide formed during catalysis promotes, indirectly, the ormation of either disulfide bonds or dityrosine crosslinks, or both, in the gluten network [7] Addition of increasing glucose oxidase concentrations to wheat flour dough produced significant changes on dough rheology and bread quality; and the extent of the effect was highly dependent on the amount of enzyme and the original wheat flour quality.

The obtained results indicate that the use of the "Gluzim Mono 1000" ensures the strengthening of the gluten of the flour while increasing the water absorption capacity of flour. That, in turn, leads to an improvement of the structural and mechanical properties of the dough during the processing of flour with a weak gluten, both during its mixing and in the process of fermentation. The technological effect will be improve the adhesion properties of the dough, which will facilitate the work of dough and dough forming machines and reduce production losses. In addition, it can be assumed that the strengthening of the gluten-free dough frame will positively affect the gas-retaining ability of the dough, and hence the uniformity of the bread.

These enzymes can be added to reduce mixing time, to decrease dough consistency, to assure dough uniformity, to regulate gluten strength in bread, to control bread texture and to improve flavour. In addition, proteases have largely replaced bisulfite, which control consistency through reduction of gluten protein disulfide bonds, while proteolysis breaks down peptide bonds. In both cases, the final effect is a similar weakening of the gluten network.

\section{REFERENCES}

[1] Whitehurst, R. J., \& Van Oort, M. (Eds.). (2009). Enzymes in food technology. John Wiley \& Sons, Singapore (2010).

[2] Ingredients 2016. Official Directory of the Union of Food Ingredients (2016). Moscow, SPPI (2016).

[3] AACC Method no 54-21 (2000). Approved Methods (formerly Cereal laboratory methods, 7th edn) of the American Association of Cereal Chemists, American Association of Cereal Chemists, St Paul, MN.

[4] Locken, L. (1972). The farinograph handbook. In American Association of Cereal Chemists, eds. Locken, L., Loska, S. and Shney, W.C. St Paul, MN.

[5] AACC International. (2014), Approved Methods of Analysis, 11th Ed., Approved Methods 10-05.01, 44-15.02, 54-10.01, 54-21.01, 54-60.01, 54-70.01.AACC International, St. Paul, $\mathrm{MN}$.

[6] Serna-Saldivar, S. O. (2012). Cereal grains: laboratory reference and procedures manual. CRC Press. (2012).

[7] Tilley KA, Benjamin RE, Bagorogoza KE, Okot-Kotber BM, Prakash O, Kwen H. Tyrosine Cross-Links: Molecular Basis of Gluten Structure and Function. Journal of Agricultural and Food Chemistry 2001;49 (5) 2627-2632. 